\title{
Extreme secondary sexual dimorphism in the genus Florarctus (Heterotardigrada: Halechiniscidae)
}

\author{
Piotr Gąsiorek ${ }^{1}$ (i) $\cdot$ David Møbjerg Kristensen ${ }^{2,3}$ (D) $\cdot$ Reinhardt Møbjerg Kristensen ${ }^{4}$ (D)
}

Received: 14 October 2020 / Revised: 3 March 2021 / Accepted: 15 March 2021 / Published online: 28 May 2021

(C) The Author(s) 2021

\begin{abstract}
Secondary sexual dimorphism in florarctin tardigrades is a well-known phenomenon. Males are usually smaller than females, and primary clavae are relatively longer in the former. A new species Florarctus bellahelenae, collected from subtidal coralline sand just behind the reef fringe of Long Island, Chesterfield Reefs (Pacific Ocean), exhibits extreme secondary dimorphism. Males have developed primary clavae that are much thicker and three times longer than those present in females. Furthermore, the male primary clavae have an accordion-like outer structure, whereas primary clavae are smooth in females. Other species of Florarctus Delamare-Deboutteville \& Renaud-Mornant, 1965 inhabiting the Pacific Ocean were investigated. Males are typically smaller than females, but males of Florarctus heimi Delamare-Deboutteville \& Renaud-Mornant, 1965 and females of Florarctus cervinus Renaud-Mornant, 1987 have never been recorded. The Renaud-Mornant collection was re-examined, and type series were analysed. Florarctus heimi and F. cervinus were always found together in the coralline sand of Heron Island (Great Barrier Reef). The animals were kept alive and surveyed in the laboratory of the Queensland Museum. All studied individuals of the larger $F$. heimi (up to ca. $400 \mu \mathrm{m}$ ) were females, and all adults of the smaller $F$. cervinus (about $170 \mu \mathrm{m}$ ) were males. Males of $F$. cervinus were observed mating with females of $F$. heimi. Following those morphological and behavioural lines of evidence, we propose that $F$. cervinus is a junior synonym of $F$. heimi. Based on the discovery of dimorphism in $F$. bellahelenae sp. nov. and the strong sex-related morphological disparities in $F$. heimi, we suggest that extreme secondary dimorphism may be present in other florarctin arthrotardigrades.
\end{abstract}

Keywords Clavae $\cdot$ Fertilisation $\cdot$ Mating behaviour $\cdot$ Meiofauna $\cdot$ Tardigrades

This article is registered in ZooBank under http://zoobank.org/ E1A494B3-44AF-4BB3-A3D6-C059AEFF1910

Communicated by A. Martínez

Piotr Gąsiorek

piotr.lukas.gasiorek@gmail.com

Reinhardt Møbjerg Kristensen

rmkristensen@snm.ku.dk

1 Department of Invertebrate Evolution, Faculty of Biology, Jagiellonian University, Gronostajowa 9, 30-387 Kraków, Poland

2 Department of Neurology, Danish Headache Center, Rigshospitalet, University of Copenhagen, Copenhagen, Denmark

3 Institut national de la santé et de la recherche médicale, École des hautes études en santé publique, University of Rennes, Research Institute for Environmental and Occupational Health, UMR S 1085, 35000 Rennes, France

4 Natural History Museum of Denmark, University of Copenhagen, Universitetsparken 15, 2100 Copenhagen, Denmark

\section{Introduction}

Meiofauna comprises microscopic animals (Schmidt-Rhaesa 2020), some of which were often referred to as "smaller neglected phyla" (e.g. Kershaw 1983; Blaxter et al. 2004). This is probably because meiofauna has been largely understudied in many aspects, such as the lack of biodiversity surveys and the unknown overall species richness (CuriniGalletti et al. 2012), through uncertain conservation needs (Roberts et al. 2002; Martínez et al. 2020), to obscure role in ecosystem functioning (Schratzberger and Ingels 2018). In tardigrades, there has been an additional bias towards studying limno-terrestrial lineages, while marine taxa have been left relatively unexplored (Bartels et al. 2016).

Unsurprisingly, mating, copulation and related sexual reproduction behaviours remain generally poorly investigated for most meiofaunal organisms. There is a single report on Kinorhyncha (Neuhaus and Higgins 2002), two studies on Gastrotricha (Ruppert 1978a, 1978b), and a few studies on 
monogonont Rotifera (Gilbert 1963; Rico-Martínez and Snell 1997; Velázquez-Rojas et al. 2002; Rico-Martínez and Walsh 2013) and Tardigrada, although restricted to limno-terrestrial species (Bingemer et al. 2016; Sugiura et al. 2019; Bartel and Hohberg 2020). Representatives of other phyla, such as Loricifera (Kristensen 1983) or Gnathostomulida (Sterrer and Sørensen 2015), have never been observed while mating. Mating-associated behaviours in microscopic metazoans are a tabula rasa, despite the anatomy of reproductive system, and especially of parts presumed to be involved in copulation being an important character used in the systematics of some phyla, such as Gnathostomulida (Sterrer 1972) or Tardigrada (Degma and Guidetti 2018). Moreover, species identification in marine heterotardigrades also relies on genital anatomy (Kristensen and Hallas 1980; D'Addabbo Gallo et al. 1989; Kristensen and Higgins 1989; Pollock 1995; Bartels et al. 2018). Given that the genital traits have been extensively utilised in systematics, unravelling the ethological background of courtship and reproduction may likewise provide an insight into the classification of animals (e.g. Thiel and Duffy 2007).

In contrast to the exclusively microscopic tardigrades and loriciferans, the reproductive biology of phyla comprising both macrofauna and microfauna has been more thoroughly investigated and includes studies into the sexual dimorphism and parental care in annelids (Jouin 1968; Sella and Ramella 1999), mating behaviours in free-living planktonic nematodes and copepods (Jensen 1982; Uchima and Murano 1988; Buskey 1998), insemination in microscopic annelids and gastropods (Westheide 1978; Jörger et al. 2009), copulation in kalyptorhynchs and chaetognaths (Nagasawa 1985; Doe and Smith 2016) and parental care in amphipods and hermaphroditic polyclads (Thiel 1999; Rawlinson et al. 2008). The wide array of the reproductive biology topics unstudied, or poorly studied, in tardigrades means that we still lack even basic knowledge about reproduction in this group (Altiero et al. 2018)

Marine tardigrades belong predominantly to the class Heterotardigrada (Hansen 2011; Fontoura et al. 2017), with few representatives of the Eutardigrada inhabiting the sea (Ramazzotti 1972; Tsurusaki 1980; Kristensen 1982; Gassiorek et al. 2019; Hansen and Kristensen 2020). Heterotardigrades have the gonopore separated from anus (Dewel et al. 1993; Møbjerg et al. 2018) and can be either gonochoristic (Jørgensen et al. 2014) or hermaphroditic (Suzuki and Kristensen 2014) taxa, the latter represented by only one species, Orzeliscus belopus du Bois Reymond Marcus, 1952 so far. Pacific florarctins (Halechiniscidae) have been the subject of systematic faunistic studies (DelamareDeboutteville and Renaud-Mornant 1965; Renaud-Mornant 1967, 1987, 1989; Kristensen 1984; Noda 1987; Chang and Rho 1997; Jørgensen et al. 2014; Bartels et al. 2015; Fujimoto 2015). This subfamily is particularly interesting due to the presence of epicuticular vesicles with endosymbiotic bacteria (Kristensen 1984), and a broad spectrum of sexual dimorphism, as sex-collection, is the goal of the present paper in Ligiarctus Renaud-Mornant, 1982 (Gomes-Júnior et al. 2018) and Wingstrandarctus Kristensen, 1984 (Kristensen 1984) but well marked in Florarctus Delamare-Deboutteville \& Renaud-Mornant, 1965 (Renaud-Mornant 1989). Sexspecific differences have been described in recent papers about Florarctus from the Ionian Sea and the Caribbean (Hansen et al. 2016; Anguas-Escalante et al. 2020). In this paper, we elaborate on the sexual dimorphism and provide a detailed description of mating behaviour, in this mostly subtropical-tropical genus (e.g. Renaud-Mornant 1976; Gallo et al. 2007), observed in specimens collected from the Great Barrier Reef. This inclined us to summarise current knowledge regarding mating in tardigrades. As a corollary of our results, we conclude that descriptions of new arthrotardigrades belonging to genera with known sexually dimorphic species, and represented by only a single sex within samples, should be avoided as this may deepen the confusion in systematics caused by synonymies resulting from incomplete works.

\section{Material and methods}

In May of 1979, Niels Svennevig collected 12 samples of coralline sand from different coral reefs along the east coast of Australia and the Chesterfield Islands in the Coral Sea. The samples were collected from the surface of the sediments while diving at $2 \mathrm{~m}$ depth, and subsequently bulk fixed in $4 \%$ neutralised formaldehyde. Five years later, in the laboratory of the University of Copenhagen, tardigrades were extracted in fresh water by decanting the detritus from the samples through mermaid-bra nets with a mesh size of $30 \mu \mathrm{m}$ and $62 \mu \mathrm{m}$. All the investigated samples contained arthrotardigrades, including specimens belonging to the genus Wingstrandarctus (Kristensen 1984) and material from an atypical, undescribed species of Florarctus. The description of this last species, 40 years after its collection, is the goal of the present paper. Finally, new material of Florarctus heimi Delamare-Deboutteville \& RenaudMornant, 1965 and Florarctus cervinus Renaud-Mornant, 1987 was collected from Shark Bay, Heron Island, between 1995 and 1996 (Kristensen 2003). Type material of these species was borrowed by Hansen (2011) from the National Museum of Natural History in Paris, where Jeanne RenaudMornant had held the position of curator of Tardigrada.

The detailed drawings of specimens on microslides were made based on specimens mounted in distilled water using a camera lucida. The water was subsequently replaced with glycerol, following an increased concentration series (5\%, $10 \%, 25 \%, 50 \%$ and $100 \%$ ), by placing the new media on 
the side of the microscope slide coverslip. After the process, the animals were removed from the camera lucida slide, immersed in $100 \%$ glycerol or polyvinyl lactophenol (PVL; female NHMD-636745) and sealed using Glyceel®. The specimens on the microslides were studied using a light microscope with phase (PCM) or Nomarski (DIC) interference contrast. Micrographs were taken using an Olympus C-3030 zoom digital camera mounted either on an Olympus BX51 or on a Leica DM-RXA microscope. By drawing the specimens in distilled water, we were able to examine many structures that are otherwise invisible in glycerol-mounted material, and usually only reported from transmission electron microscopy (TEM) observations. These structures include different glands ("one-celled" glands, head glands, segmental ventral/dorsal glands and the two vesicles with symbiotic bacteria) and elements of the bucco-pharyngeal apparatus (stylets, placoids). The terminology follows Fontoura et al. (2017).

\section{Results}

\section{Systematic account}

Phylum: Tardigrada Doyère, 1840

Class: Heterotardigrada Marcus, 1927

Order: Arthrotardigrada Marcus, 1927*

Family: Halechiniscidae Thulin, 1928 (amended by Fujimoto et al. 2017)

Subfamily: Florarctinae Renaud-Mornant, 1982 (amended by Kristensen 1984)

Amended diagnosis: Halechiniscids with cuticular aliform expansions (alae) with or without caestus. Cephalic sense organs without tertiary clavae, strong secondary dimorphism in the primary clavae, secondary clavae transformed to domeshaped papillae or H-shaped flat sacs. Usually, two to three cephalic vesicles containing symbiotic bacteria. Ventral segmental glands in all segments, opening near the insertion of coxae of the legs. Six to seven pairs of epidermal "one-cell" glands in total, found in the head and in the trunk. Four toes with claws present in adults, digitus externus with a hookshaped pedunculus; uncus with calcar externum, digitus internus with a simple hook-shaped claw bearing a tiny dorsal spur. Males with ovoid gonopore close to anus. Females always with two seminal receptacles, each consisting of a spheroid vesicle with spermatozoa and an S-shaped genital duct opening laterally with a small papilla (anterior or posterior), entirely separated from the six-lobed (hexpartite/rosette) female gonopore. Anus three-lobed.

* Arthrotardigrada are a paraphyletic group with respect to the monophyletic Echiniscoidea (Fujimoto et al. 2017), and their systematic rank as an order is maintained herein only traditionally.
Genus: Florarctus Delamare-Deboutteville \& RenaudMornant, 1965

Species: Florarctus bellahelenae sp. nov. http://zoobank.org/1F3A6A04-1296-411D-BDB8-0FCA73FF4F9A

Type material: Holotype (female) NHMD-636744, allotype (male) NHMD-636740, three paratypic males (NHMD636741-3) and three paratypic females (NHMD-636745-7) that are in poor condition on the slides after 40 years. Table 1 provides the measurements for morphological characteristics. All type specimens and the remaining coralline sediment are preserved in the Natural History Museum of Denmark.

Type locality: North Cay of Long Island, Chesterfield Reefs (Pacific Ocean) at the GPS position: $19^{\circ} 53^{\prime} 00^{\prime \prime} \mathrm{S}$, $158^{\circ} 19^{\prime} 00^{\prime \prime} \mathrm{E}$.

Etymology: From Latin bella (masc. bellus $)=$ beautiful + Helen; noun in genitive singular. The specific epithet has a twofold sense as (1) it honours Helene Møbjerg Boslev Kristensen for all the travels she has undertaken with us to collect tardigrades around the world; (2) Helen was the abducted queen of Sparta, sworn to prince Paris of Troy by Aphrodite. The morphology of $F$. bellahelenae strongly suggests that males, using their enormously long primary clavae, spend a substantial part of their life searching for (beautiful) females, as the Achaeans did in order to reclaim Helen, which ultimately resulted in the downfall of Troy.

\section{Description of the holotypic female of Florarctus bellahelenae sp. nov. (Figs. 1 and 2)}

NHMD-636744. Stored in a 100\% glycerol microslide after fixation in $4 \%$ buffered formalin.

The body of the female is $149 \mu \mathrm{m}$ long and $87 \mu \mathrm{m}$ wide. Cuticle smooth, regularly (metamerically) folded on the dorsal side. The head (Figs. 1 and 2) is distinct from the trunk and has the following set of sense organs: cephalic cirri and clavae; the primary clavae (chemoreceptors) have a standard length (61 $\mu \mathrm{m})$, and their shape is as in all other florarctin species. The median cirrus $(\mathrm{mc}, 19 \mu \mathrm{m})$ arises middorsally and is placed distally to the anterior margin of the head, which has a very large rostral ala (ra). Three gland cells are located at the base of the median cirrus (rg, Fig. 1), as in the allotype (see below). The internal cirri $(31 \mu \mathrm{m})$ are placed dorsally, partly outside the rostral ala (ra). The external cirri $(24 \mu \mathrm{m})$ are smaller and located ventrally. Cirrus $A$ is difficult to measure, because it is covered by the primary clava, but its length is ca. $38 \mu \mathrm{m}$. The secondary clavae are fused (sc) and can be clearly observed from the ventral side in the holotype. The two vesicles with bacteria (vc) are very large. All four legs have setae $\left(\mathrm{se}_{1}\right.$ to $\left.\mathrm{se}_{4}\right)$. The seta on the fourth leg has a blunt tip and is not spine-shaped. Cirrus $E$ consists of a large cirrophore, a well-developed scapus with a characteristic spiral structure and a long flagellum. The flagellum comprises two parts: an internal layer, with a diameter almost the same as the scapus, 
Table 1 Measurements (in $\mu \mathrm{m}$ ) of selected morphological structures of the type series of Florarctus bellahelenae sp. nov.

\begin{tabular}{|c|c|c|c|c|c|c|c|}
\hline \multirow[t]{3}{*}{ Character } & \multirow[t]{3}{*}{ Holotype $q$} & \multirow{3}{*}{\multicolumn{2}{|c|}{ Allotype $\hat{\sigma}$}} & \multicolumn{4}{|c|}{ Paratypes } \\
\hline & & & & \multicolumn{2}{|c|}{$\widehat{\partial} \widehat{\partial}$} & \multicolumn{2}{|c|}{ 우우 } \\
\hline & & & & $N$ & Range & $N$ & Range \\
\hline Body length & 149 & 85 & & 3 & $101-110$ & 3 & $123-144$ \\
\hline Body width & 87 & 61 & & 3 & $54-64$ & 3 & $74-84$ \\
\hline Median cirrus & 19 & 19 & & 1 & 24 & - & $?$ \\
\hline Internal cirrus & 31 & 31 & & 2 & $37-44$ & - & $?$ \\
\hline External cirrus & 24 & 24 & & 1 & 24 & - & $?$ \\
\hline Lateral cirrus $A$ & 38 & 28 & & 2 & $32-33$ & - & $?$ \\
\hline Primary clava & 61 & 157 & & 3 & $188-192$ & 3 & $42-51$ \\
\hline Cirrus $E$ & 35 & $\begin{array}{l}\mathrm{cf}=8 \\
\mathrm{sp}=9 \\
\mathrm{fl}=27\end{array}$ & 44 & 2 & $39-42$ & 1 & 37 \\
\hline Sense organ on leg I & 13 & 14 & & - & $?$ & - & $?$ \\
\hline Sense organ on leg II & 12 & 12 & & - & $?$ & - & $?$ \\
\hline Sense organ on leg III & 10 & 10 & & - & $?$ & - & $?$ \\
\hline Sense organ on leg IV & 11 & 14 & & - & $?$ & - & $?$ \\
\hline
\end{tabular}

$N$ is the number of structures measured and an external part, which is observable only under PCM. The entire cirrus is $35 \mu \mathrm{m}$ long. As in many florarctin tardigrades, there are two particularly large lateral vesicles, containing symbiotic bacteria in all females (vc, Fig. 1). The two large unicellular structures ( $\mathrm{hg}=$ head gland) and the three dorsal segmental glands (dg) cannot be observed in ventral view in the holotype. However, the ventral segmental glands (vg) are visible in the head and in all four trunk segments. In the trunk, the glands open close to the coxae. Only one pair of refractive glands, called "one-cell" epidermal glands (og, Figs. 1 and 5e), is present in the head of the holotype; however, five pairs exist in the trunk. The bucco-pharyngeal apparatus is more visible in the allotype.

The legs consist of coxa, femur, tibia and tarsus. The claws have unique structures found only in florarctins. A dorsal spur is present only on the internal claws, whereas each external claw has an avicularium appearing as a small notch, and a prominent dorsal calcar. Strong hook-shaped peduncles are seen at the base of the external digits in all leg pairs. The hooks of the peduncles are partly inserted in the tarsus.

The female reproductive system is fully mature. Only one large oocyte (ov) appears to mature at a time. Two seminal receptacles (rs) are filled with mature spermatozoa. The efferent genital ducts originating from these round vesicles are S-shaped and open, as two small papillae, posterolaterally from the six-lobed female gonopore. The female gonopore is located distally $(20 \mu \mathrm{m})$ to the posterioventral trilobed anus.

The alae consist of a very large rostral ala (ra) and two lateral alae, where the first and second lateral alae $\left(\mathrm{l}_{1}\right.$ and $\mathrm{la}_{2}$ ) are clearly separated by a fold, and $\mathrm{la}_{1}$ is further divided into two unequal parts, hence the lateral alae are labelled as $\mathrm{la}_{1}$ to $\mathrm{la}_{3}$. The caudal ala is well developed and consists of four lobes. There are four pairs of caesti $\left(\mathrm{c}_{1}\right.$ to $\left.\mathrm{c}_{4}\right)$ : anterolateral $\mathrm{c}_{1}$ at the level of legs I, and $c_{2}$ between legs II and III; posterolateral $c_{3}$ between legs III and IV; and simple (not ramified) caudal caesti $\mathrm{c}_{4}$ (caesti do not extend laterally to the external edge of the alae; Fig. 1). These structures comprise both epicuticle with pillars, and procuticle (see Kristensen 1984). A new feature in $F$. bellahelenae is the long supporting structure in the first lateral ala $\left(\mathrm{la}_{1}\right)$ seen in both the holotypic female and the allotypic male. This new structure, the head ala support (ha), consists of the procuticle that extends to the external edge of the ala. The head ala support is located just in front of the first caestus $\left(\mathrm{c}_{1}\right)$. A similar structure appears to be present in the posterior part of the first lateral ala and forms the boundary between $1 \mathrm{a}_{1}$ and $1 \mathrm{a}_{2}$.

\section{Description of the allotypic male of Florarctus bellahelenae sp. nov. (Figs. 3 and 4)}

NHMD-636740. Data as for the holotype.

The body of the allotype is $85 \mu \mathrm{m}$ long and $61 \mu \mathrm{m}$ wide. The head and peribuccal cirri (Figs. 3, 4 and 5a) are identical to those in the holotypic female; however, the primary clavae are much thicker and nearly three times longer $(157 \mu \mathrm{m})$ than those in the holotypic female $(61 \mu \mathrm{m})$ and are thereby completely different from all other florarctin species or any other marine heterotardigrades. Furthermore, the allotypic primary clavae have an accordion-like outer structure (Fig. 5b), not seen previously in any arthrotardigrade. The median cirrus $(\mathrm{mc}, 19 \mu \mathrm{m})$ arises middorsally and is distant from the anterior margin of the head, 



Fig. 1 Habitus drawing of the holotypic female of Florarctus bellahelenae sp. nov. (ventral view). Locality: Long Island, Chesterfield Reefs (Pacific Ocean). List of abbreviations: an, anus; br, brain; $\mathrm{c}_{1-4}$, caesti; ca, caudal ala; $\mathrm{cE}$, cirrus $E$; cf, cirrophore; dg, dorsal segmental gland; ec, cirrus externus; ed, digitus externus; ex, ala with both internal (endocuticle) and external (epicuticle) supporting cuticle; fl, flagellum; go, gonopore; ha, long head supporting structure in the first lateral ala; hg, head gland; ic, cirrus internus; id, digitus internus; la ${ }_{1-3}$, lateral alae;

which has a very large rostral ala (ra). At the base of the median cirrus, there are two to four rostral gland cells (more clearly seen in the holotypic female) (rg, Figs. 1 and 5d). The internal cirri (31 $\mu \mathrm{m})$ are placed dorsally, and part of the scapus (sp) and the entire flagellum (fl) extend beyond the rostral ala (ra). The external cirri are shorter $(24 \mu \mathrm{m})$ and located ventrally. The cirrus $A$ length is about $28 \mu \mathrm{m}$. The secondary clavae are fused but cannot be lc, cirrus A; mc, cirrus medianus; og, "one-cell" epidermal gland; ov, oocyte in ovary; pb, pharynx; pc, primary clava; ra, rostral ala (= frontal ala in Fujimoto 2015); rg, rostral gland; rs, seminal receptacle (= receptaculum seminis); $\mathrm{sc}$, secondary clava; $\mathrm{se}_{1-4}$, sense organs on legs; sm, star-like dorsal muscle; sp, scapus; sv, seminal vesicle; sz, spermatozoa; te, testis; vc, cephalic vesicle with symbiotic bacteria; vg, ventral segmental gland; vl, van der Land's body inside primary clava

observed from the dorsal side. The fourth leg seta $\left(\mathrm{se}_{4}\right)$ may be modified by having a blunt tip. Cirrus $E$ is the same as in the female holotype (Fig. 5c). The whole structure is $44 \mu \mathrm{m}$ long. There are two small lateral vesicles containing symbiotic bacteria (vc, Fig. 3). Totally unique in the head of the allotype are two large unicellular structures ( $\mathrm{hg}=$ head glands) similar to the dorsal segmental glands (dg) seen in the trunk. Although only three pairs 


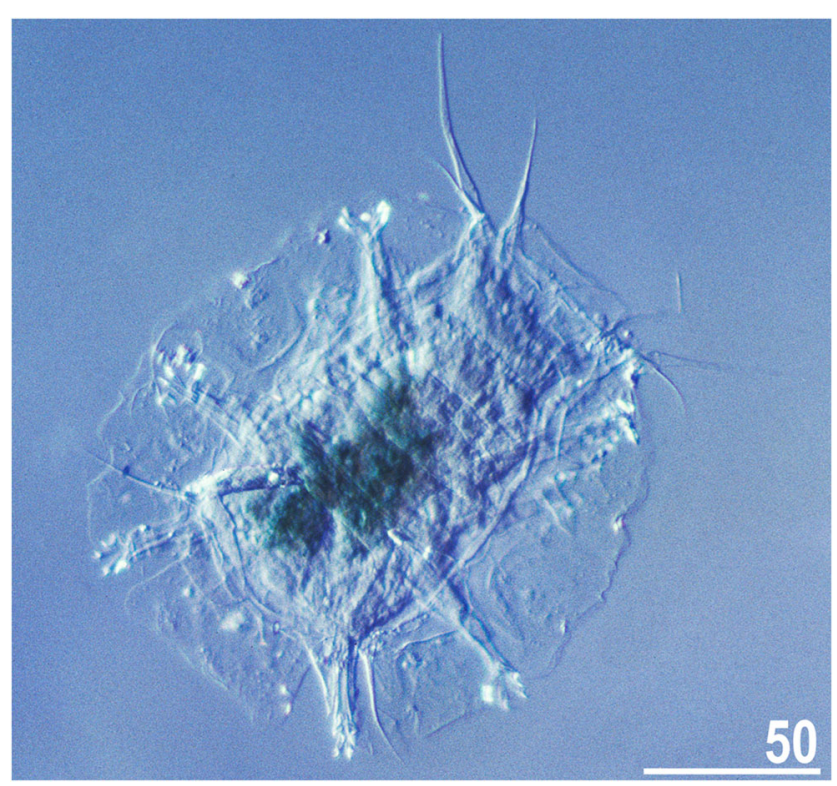

Fig. 2 Habitus image of the holotypic female of Florarctus bellahelenae sp. nov. (ventral view, DIC). Scale bar in $\mu \mathrm{m}$

were observed, a fourth pair may be hidden under the large seminal vesicles (sv). A unique dorsal structure of the new species among all florarctin tardigrades is the star-like cross-striated muscle (sm) of the caudal segment (its presence in other taxa requires further investigation). The buccal tube is relatively short (ca. $19 \mu \mathrm{m}$ long). The stylets are short compared with other florarctins (22 $\mu \mathrm{m}$ long) and lack stylet supports (Fig. 5e, f). The pharyngeal bulb has three large apodemes in front of the three straight placoids. The placoids are short and slender. Unfortunately, all pharyngeal structures dissolved in the glycerol preparation.

The reproductive system comprises a small testis and two large seminal vesicles with two ventral ducts opening directly into the oval male gonopore located anteriorly of the trilobed anus. The gonopore/anus distance is very small $(2.5 \mu \mathrm{m})$. The seminal vesicles contain only about 100 late-stage spermatids with the characteristic wheat grain-shaped head. The tail (flagellum) in the spermatids is difficult to observe as the final stage of the male germ cells (spermatozoa) only develops in the female seminal receptacles.

Alae arranged as in the holotype. The first lateral ala is divided into two almost equal sections, with the anterior section the longest. Caesti inside the alae consist of single, unbranched projections $\left(\mathrm{c}_{1}-\mathrm{c}_{4}\right)$. The head ala support (ha) is present, but it is indistinct and does not appear to extend through the full width of the ala.

\section{Differential diagnosis}

The absence of any form of mammiliform sculpture on the dorsal cuticle (smooth with only metameric folds in Florarctus bellahelenae sp. nov.) and the presence of continuous lateral caesti in the alae are shared by Florarctus antillensis van der Land, 1968, Florarctus glareolus Noda, 1987, Florarctus pulcher de Zio Grimaldi et al., 1999, Florarctus wunai Fujimoto, 2015 and Florarctus yucatanensis Anguas-Escalante et al., 2020 and the new species. Males of Florarctus bellahelenae sp. nov. can be easily distinguished from all described Florarctus species based on the accordion-like form of the primary clavae. Females can be distinguished from the following:

- Florarctus antillensis, based on the body size ( $F$. bellahelenae sp. nov. does not reach $150 \mu \mathrm{m}$ in length vs up to $300 \mu \mathrm{m}$ in $F$. antillensis), and the sculpturing of leg setae (sculpture absent in $F$. bellahelenae sp. nov. vs the rugose cuticle present in $F$. antillensis);

- Florarctus glareolus, based on the position of the seminal receptacles (positioned far away from the gonopore, at the level of the anus in $F$. bellahelenae sp. nov. vs placed at the same distance from gonopore and anus in F. glareolus);

- Florarctus pulcher, based on the shape of the caudal caesti $\mathrm{c}_{4}$ (pillar-like in $F$. bellahelenae sp. nov. vs clubshaped in $F$. pulcher);

- Florarctus wunai, based on the shape of the caudal caesti $\mathrm{c}_{4}$ (pillar-like in $F$. bellahelenae sp. nov. vs papilla-shaped in F. wunai);

- Florarctus yucatanensis, based on the shape of both the lateral and caudal caesti (caesti simple, not lobed or ramified in F. bellahelenae sp. nov. vs anterolateral caesti with bilobed posterior projections, and caudal caesti with lateral projections in F. yucatanensis), and the dorsal cuticular wrinkling (absent in $F$. bellahelenae sp. nov. vs present in F. yucatanensis).

Species: Florarctus heimi Delamare-Deboutteville \& Renaud-Mornant, 1965

Type material: Holotypic female (MNHN, Paris, A1278/ $50 \mathrm{Ma})$ and one paratypic female (MNHN, Paris, MA8/ 551Ma). From New Caledonia.

New material: Additional specimens (Figs. 6, 78 and 9) from coralline sand collected by D. M. Kristensen and R. M. Kristensen at Shark Bay, Heron Island, Australia (23 $26.8^{\prime} \mathrm{S}$, $\left.151^{\circ} 55.18^{\prime} \mathrm{E}\right)$, on 13 December 1995, later deposited in the Zoological Museum, Copenhagen, Denmark (Kristensen 2003).

1. NHMD-672675. Two specimens: male and female mounted in glycerol. Male represents former F. cervinus. Male: length, $192 \mu \mathrm{m}$; width, $110 \mu \mathrm{m}$. Female: length, $285 \mu \mathrm{m}$; width, $163 \mu \mathrm{m}$.

2. NHMD-672676. Two specimens: male and female mounted in glycerol. Male represents former F. cervinus. Male: length, $170 \mu \mathrm{m}$; width, $94 \mu \mathrm{m}$. Female: length, $224 \mu \mathrm{m}$; width, $143 \mu \mathrm{m}$. 




Fig. 3 Habitus drawing of the allotypic male of Florarctus bellahelenae sp. nov. (dorsal view). Locality: Long Island, Chesterfield Reefs (Pacific Ocean). See the legend of Fig. 1 for abbreviations

3. NHMD-672678. Female mounted in glycerol. Length: $246 \mu \mathrm{m}$; width: $164 \mu \mathrm{m}$.
4. NHMD-672679. Male mounted in glycerol. Length: 176 $\mu \mathrm{m}$; width: $101 \mu \mathrm{m}$. 


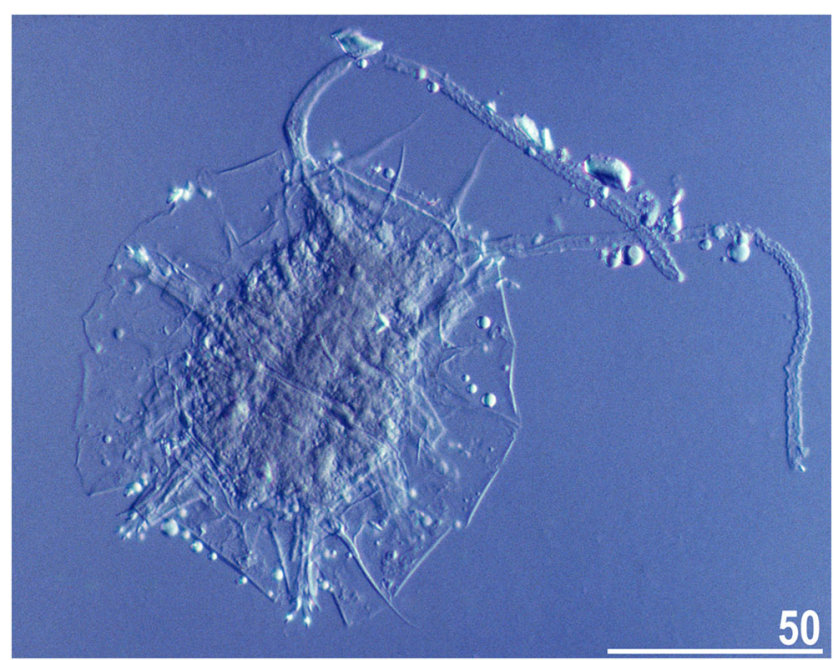

Fig. 4 Habitus image of the allotypic male of Florarctus bellahelenae sp. nov. (dorsal view, DIC). Scale bar in $\mu \mathrm{m}$

While establishing the genus Florarctus, DelamareDeboutteville and Renaud-Mornant (1965) made a detailed description of its type species Florarctus heimi. However, due to the lack of other comparable congeneric species (except for Florarctus salvati Delamare-Deboutteville and RenaudMornant, 1965 described therein), some details were not studied attentively. The holotypic female is in the early stage of moulting. The new alae are captured during formation and lie folded beneath the old dorsal cuticle, along the lateral margin of the body. Neither new claws nor new sense organs are recognisable. The complete shape of the secondary clavae is evident as a large sense plate, almost completely encircling the mouth cone (Fig. 10a). The internal cirri are well developed, being proportionally much larger than in other congeneric species (Fig. 10b). Also, the fourth leg sense organ, which is usually an S-shaped papilla, is a long tapering spine (longer than cirrus $E$ ) with a basal swelling and a terminal pore (Fig. 10c). Each external claw has a strong avicularium and a large calcar, whereas each internal claw has a thin accessory hook and a long delicate calcar. Furthermore, each internal claw has a small but evident avicularium appearing as a small notch (Fig. 10d). The lateral caesti, which are poorly visible in the holotype, are more apparent in the paratype. Like in $F$. antillensis, the lateral caesti are continuous along the margin of the body, with only a few relatively small processes. The caudal ala is highly complex, although no caestus is evident. A deep median incision divides the ala into two large
Fig. 5 Microphotographs of Florarctus bellahelenae sp. nov. depicting morphological details (PCM). a cirrus internus; $\mathbf{b}$ surface of primary clava; $\mathbf{c}$ cirrus $E$ and sense organ IV (a-c allotype); $\mathbf{d}$ internal head structures (female in distilled water; arrowhead indicates the frontal cephalic part); e, f buccopharyngeal apparatus (female and male in distilled water, respectively). List of abbreviations: cf, cirrophore; fc, furca; fl, flagellum; hg, head gland; og, "one-cell" epidermal gland; pb, pharynx; rg, rostral gland; sp, scapus. Scale bars in $\mu \mathrm{m}$
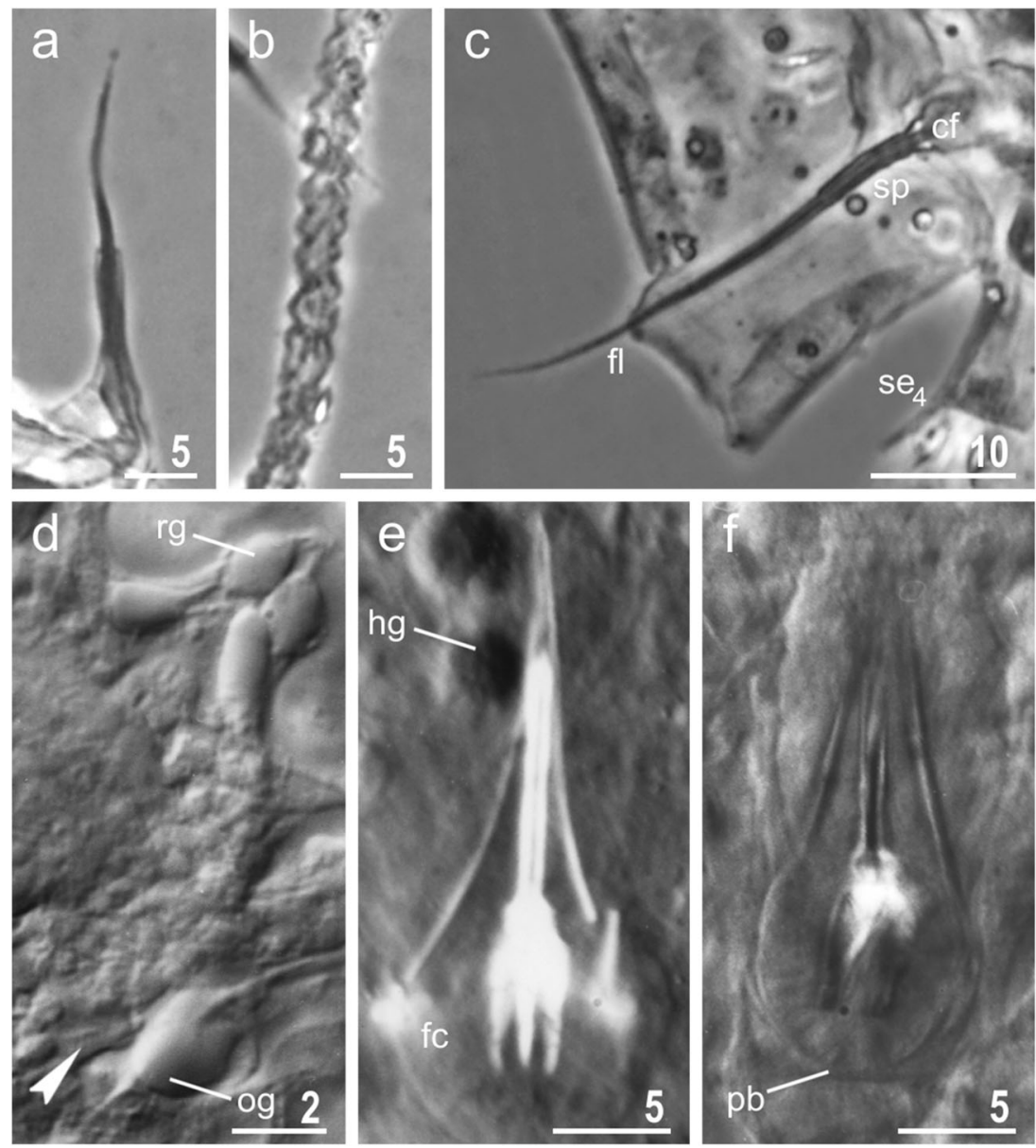


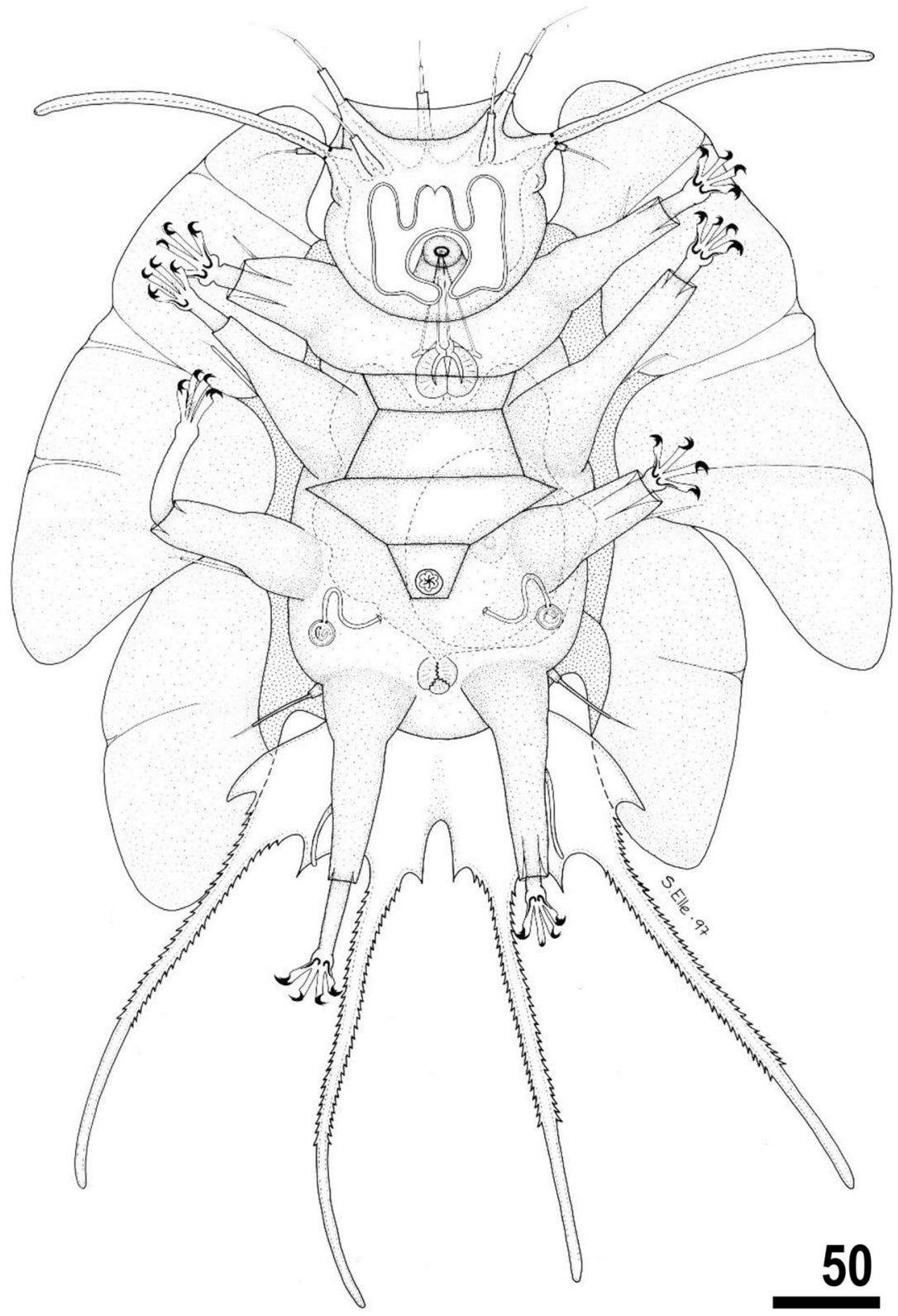

Fig. 6 Habitus drawing of the female of Florarctus heimi (ventral view). Locality: Shark Bay, Heron Island, Australia. Scale bar in $\mu \mathrm{m}$

lobes. Each lobe terminates in two long and three short spines. The caudal ala spines are not evidently serrated in the holotype, whereas they are clearly serrated in the paratype. Each spine originates near the base of the ala: the short spines as internal string-like thickenings, and the long spines as broad thickenings (Fig. 10e). The paratype is in the late stage of moulting. As in the holotype, the new alae are formed and lie folded beneath the old dorsal cuticle, along the lateral margin of the body. Interestingly, the new caudal ala and spines are not folded. Instead, the new caudal ala has an orientation opposite to that of the old caudal ala, with the spines pointing anteriorly. New legs and claws are also evident. Examination of the Australian specimens collected from Heron Island allowed us to describe not only the bucco-pharyngeal apparatus but also the male of Florarctus heimi. The stylets are thin and have large furcae; the placoids are large and curved. Three large and equally sized apophyses that appear as one highly refractive bulb are inserted anteriorly to the placoids (Figs. 6 and 7). Observations were also made of live individuals, some of which were found copulating. Surprisingly, the morphology of the males of Florarctus heimi cannot be distinguished from that of Florarctus cervinus. Based on this finding, we establish Florarctus cervinus as synonymum novum of Florarctus heimi. In conclusion, the descriptions of these two species, which were based on apparent morphological differences, in reality, represent the strong secondary sexual dimorphism displayed by Florarctus heimi. Consequently, the type material of Florarctus cervinus 


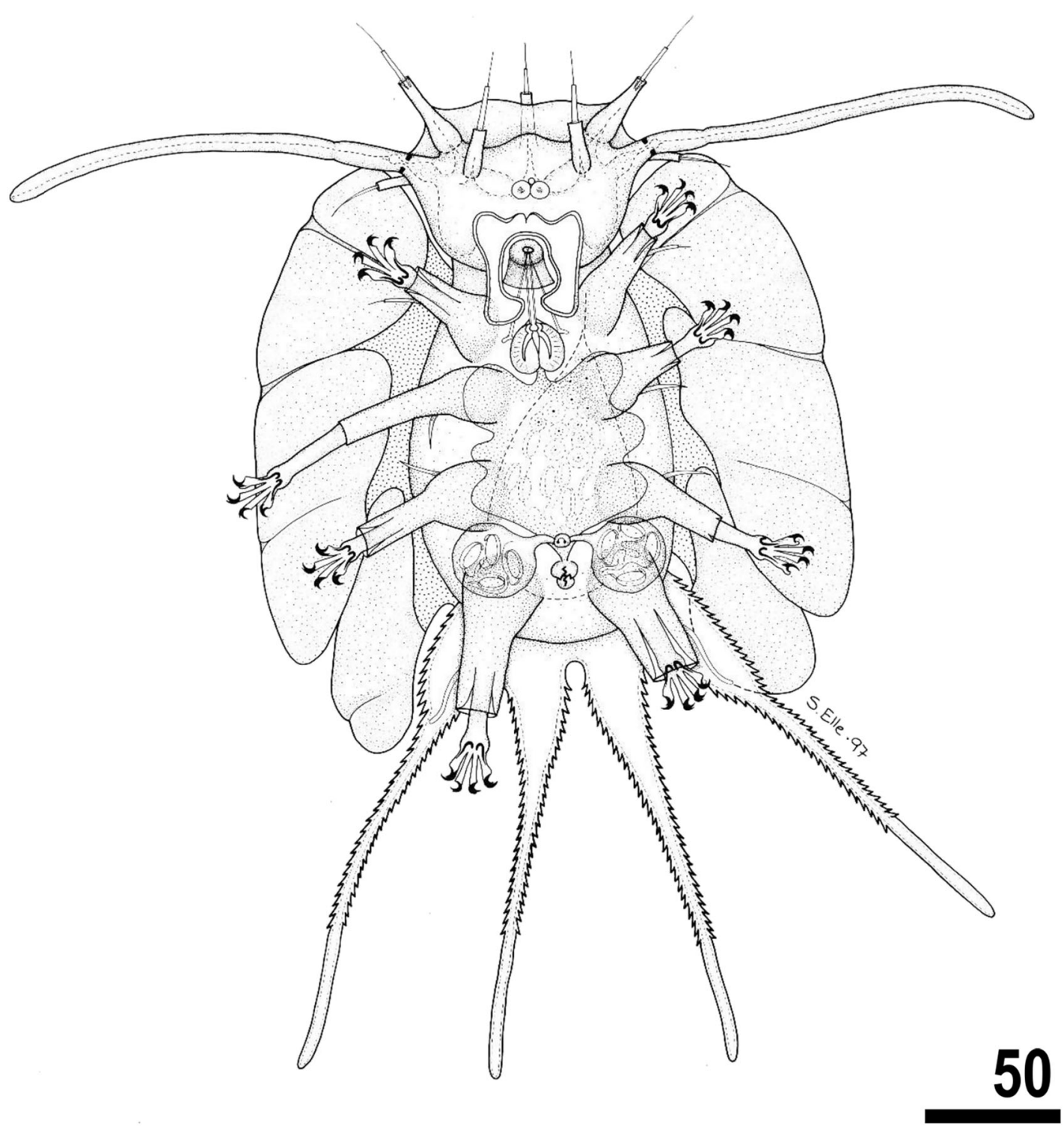

Fig. 7 Habitus drawing of the male of Florarctus heimi (ventral view). Locality: Shark Bay, Heron Island, Australia. Scale bar in $\mu \mathrm{m}$

(holotypic male [MNHN, Paris, AR593] and two paratypes [MNHN, Paris, AR594, MA6/549Ma]) is included in the type material of Florarctus heimi, thus re-designating the holotype as the allotype. As we had the opportunity for the first time to compare males and females of Florarctus heimi, the most important sexually dimorphic differences are highlighted below. The anterior margin of the rostral (frontal) ala is approximately straight in the female, whereas in the male, it has a median indentation, forming two lobes. The configuration of the lateral alae is the same in both sexes; however, the posterior lateral ala is proportionally larger in the female (compare Figs. 6 and 8 with Figs. 7 and 9). The caudal ala represents the most conspicuous difference, with the female having four long spines and six short spines (Figs. 6, 8 and 10e) and the male having only four long spines (Figs. 7 and 9). Furthermore, the caudal ala of the female is larger and has a deep medial indentation giving the impression there are two lobes. The caudal ala of the male has less deep and broadly ovate median indentation compared to that of the female (compare Figs. 6 and 7).

Differential diagnosis Florarctus heimi is currently the only representative of the genus characterised by caudal ala with long serrated spines.

\section{Discussion}

\section{Anatomy}

Several structures new to tardigrade anatomy are introduced in this contribution. The ventral segmental glands 




Fig. 8 Habitus image of the female of Florarctus heimi (ventral view, DIC). Scale bar in $\mu \mathrm{m}$

were first observed in Wingstrandarctus (Kristensen 1984) and subsequently found in nearly all arthrotardigrades. Given their location inside the organism, and orifices that open near the legs, these glands are considered to be excretory organs similar to the coxal glands in marine xiphosurans (Briggs and Moss 1997). The 'one-cell' epidermal glands undergo structural modifications during the moulting cycle and may therefore be involved in the formation of the new cuticle. These structures were first described in all species of Wingstrandarctus, but Renaud-Mornant (1989) subsequently reported their presence in Florarctus. Two to four gland cells (rostral glands) are located at the base of the median cirrus (Figs. 1 and 5d), and their putative function remains to be investigated. Head glands are present in males and identifiable as large unicellular structures. Their presence in other florarctins is yet to be demonstrated. In common with many florarctin tardigrades, including Ligiarctus (Gomes-Júnior et al. 2018), there are only two lateral vesicles with symbiotic bacteria (vc, Fig. 3) in Florarctus bellahelenae sp. nov., and not three as in Wingstrandarctus (Kristensen 1984). As Ligiarctus was

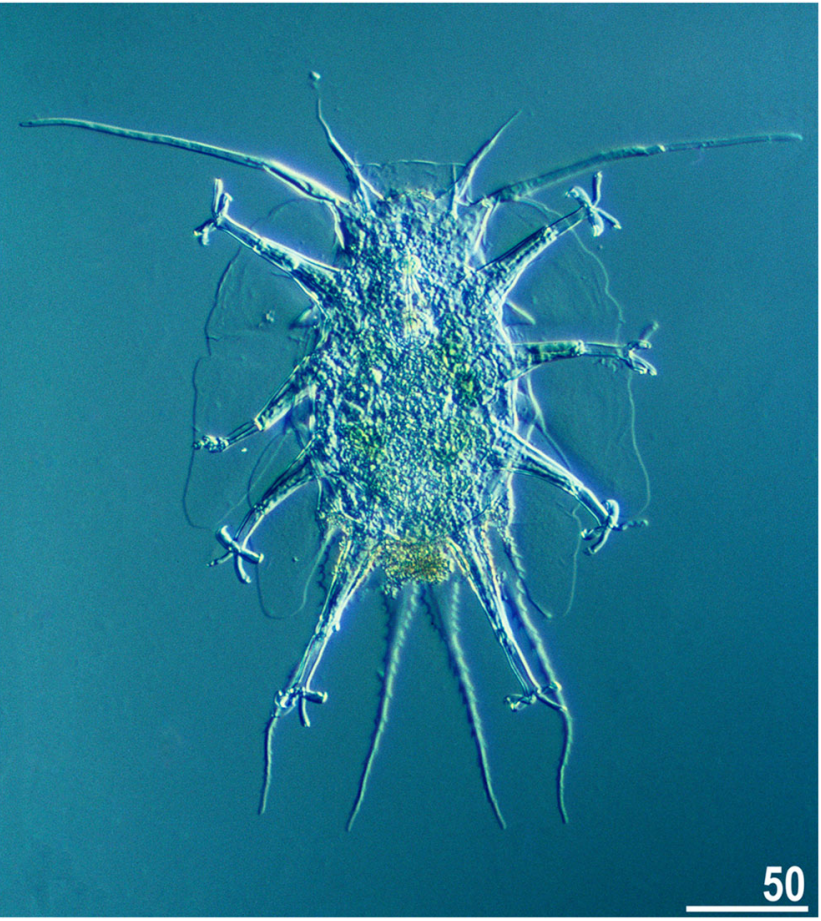

Fig. 9 Habitus image of the male of Florarctus heimi (ventral view, DIC). Scale bar in $\mu \mathrm{m}$

inferred to be the sister group of the remaining florarctins (Hansen 2011), it is hypothesised that the additional vesicle is an apomorphy of Wingstrandarctus.

\section{Mating behaviours and copulation}

A summary of knowledge relating to tardigrade pre-mating, mating and copulatory behaviours is presented in Table 2 . Strong sexual dimorphism in eutardigrades is rare and restricted to modifications of the claws on the first leg pair in males, an adaption for holding females during mating (Rebecchi and Nelson 1998; Gąsiorek et al. 2019). Recently, detailed descriptions of mating positions and sexual reproduction behaviours have been provided for representatives of Isohypsibiidae and Macrobiotidae. These observations, together with the first notes on the enticing actions males perform to initiate courtship in Batillipes noerrevangi Kristensen, 1978 (Kristensen 1979), indicate an active role for males. The probability of internal fertilisation was hypothesised for macrobiotids based on the position of the spermatheca with respect to the rectum (Sugiura et al. 2019). Elsewhere, the reproductive system of all marine tardigrades had been thoroughly investigated (Pollock 1970; Renaud-Mornant 1982). However, there was a problem with the interpretation of the so-called "annex glands" in the family Stygarctidae and the lateral vesicles in the subfamily Florarctinae. Transmission electron microscopy investigations clearly showed that both the "annex glands" and the lateral vesicles are seminal receptacles (Kristensen 1984); thus, all arthrotardigrades likely exhibit internal 
Fig. 10 Microphotographs of the holotype of Florarctus heimi depicting morphological details (DIC). a secondary clavae surrounding the mouth opening; $\mathbf{b}$ peribuccal cirri surrounding the mouth cone; $\mathbf{c}$ sense organ of leg IV; $\mathbf{d}$ claws (ed, external digit; id, internal digit); e habitus in dorsal view, showing the spine structure inside the caudal ala
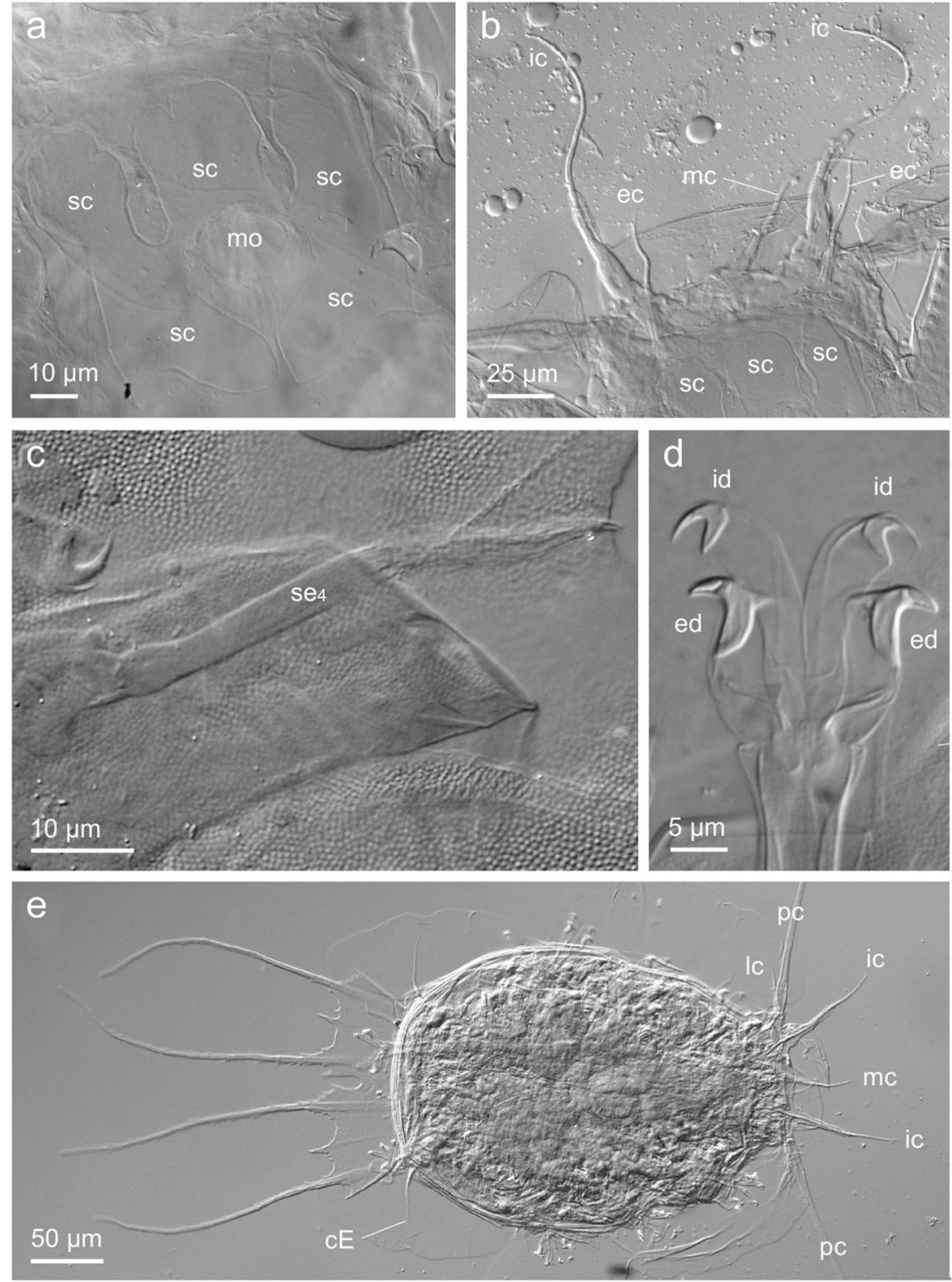

fertilisation (it needs to be stressed that seminal receptacles have not been detected in batillipedids - only enigmatic spermathecae were reported by Grimaldi de Zio and D'Addabbo Gallo 1975). Importantly, the two seminal receptacles are surrounded with cuticle so oocytes can be fertilised when a female lays freshly formed eggs into it: one in Actinarctus (Jørgensen et al. 1999) or Florarctus (Hansen et al. 2016) and up to eight eggs in Tetrakentron (Kristensen

Table 2 Summary of observations on reproductive behaviours of tardigrades

\begin{tabular}{lllll}
\hline Species & Class & Family & Main findings & Reference \\
\hline $\begin{array}{llll}\text { Batillipes noerrevangi } \\
\text { Florarctus bellahelenae sp. nov. }\end{array}$ & Heterotardigrada & Batillipedidae & Initiation of courtship reported & Kristensen (1979) \\
Isohypsibius dastychi & Eutardigrada & Isohypsibiidae & The first comprehensive description of courtship & Bingemer et al. (2016) \\
& & & Indirect evidence for pheromone signalling & Bartel and Hohberg (2020) \\
Macrobiotus shonaicus & Eutardigrada & Macrobiotidae & The second comprehensive description of courtship & Sugiura et al. (2019) \\
Milnesium inceptum & Eutardigrada & Milnesiidae & Indirect evidence for sexual signalling & Suzuki (2008) \\
$\begin{array}{lllll}\text { Parastygarctus sterreri } \\
\text { Pseudobiotus megalonyx }\end{array}$ & Heterotardigrada & Stygarctidae & Observation of ventral mating & This study \\
\hline
\end{tabular}


1980). Until now, there has only been one observation of a heterotardigrade mating behaviour in a member of Stygarctidae, Parastygarctus sterreri Renaud-Mornant, 1970, from Bermuda (R.M. Kristensen, pers. obs.). Mating ending with internal fertilisation, both in a stygarctid and in a florarctin, has been referred to as "venter-to-venter".

\section{Taxonomy}

Males are typically smaller than females in florarctins. The fact that males of $F$. heimi and females of $F$. cervinus were previously unknown, combined with the fact that both species were described from New Caledonia, should have raised some doubts regarding potential conspecificity. In December 1995, during the Australian summer, large populations of a Florarctus species were found in coralline sand collected subtidally in Shark Bay, Heron Island (the southern Great Barrier Reef). Analysis revealed two species were present, Florarctus heimi and F. cervinus, and that they were always found together. In vivo observations revealed that all specimens of the larger $F$. heimi (up to about $400 \mu \mathrm{m}$ ) were females. In contrast, all adults of the smaller $F$. cervinus (about $170 \mu \mathrm{m})$ were males. The differences in the caudal expansions of alae between the two putative species were congruent with the original descriptions. Moreover, males of $F$. cervinus were observed mating with females of $F$. heimi.

In conclusion, the morphological and behavioural evidence indicates that $F$. cervinus is a junior synonym of $F$. heimi. It is known for other microscopic animals that describing species based on individuals of a single sex might lead to an inflation of the number of species (e.g. Karanovic 2008). Only molecular data could most objectively test the assertion of their conspecificity, analogously to actions undertaken by crustacean specialists in the copepod order Monstrilloida (Jeon et al. 2018) to link sexes of one species. As a consequence, new marine heterotardigrades with strongly sexually dimorphic traits should not be described based on individuals of one sex, if only to avoid future synonymies.

\section{Biogeography}

The vast majority of records of Florarctus fall within two regions: warm oceans and warm-temperate provinces (Briggs and Bowen 2012). There are only two reports of Florarctus species (Florarctus acer Renaud-Mornant, 1989 and Florarctus hulingsi Renaud-Mornant, 1976) from cold waters of the Bay of Morlaix, North Atlantic Ocean (Renaud-Mornant and Gourbault 1980; Renaud-Mornant 1989). All records of Florarctus published since the last summary of marine tardigrade zoogeography (Kaczmarek et al. 2015) originate from tropical or subtropical areas (Fujimoto 2015; Bartels et al. 2018; Anguas-Escalante et al. 2020); therefore, we hypothesise that such clear temperature-driven regionalisation of an entire genus of marine tardigrades is uncommon; however, it has never been rigorously tested. If positively verified, such regionalisation would appear unusual as the species composition of marine tardigrade communities changes with depth (Hansen et al. 2001), exhibiting bathymetric-dependent diversity and endemicity patterns known for other animals (Rex 1973, 1981).

There are five Florarctus species: F. antillensis, F. asper Renaud-Mornant, 1989, F. cinctus Renaud-Mornant, 1976, $F$. hulingsi and F. stellatus Renaud-Mornant, 1989, that are characterised by very wide distributions, always embracing many records from the relatively well-sampled Mediterranean region and usually only some tropical locales (Kaczmarek et al. 2015). This situation seems incongruous given the recently revealed species complex in the genus Batillipes (Santos et al. 2019) from the Atlantic Ocean and the Mediterranean. Consequently, geographic ranges should be better documented in tardigrades if claims, for example that species occurring in both the Mediterranean and the Coral Sea are the same, are to be supported. In the light of this, a single report of $F$. heimi from the Maldives (Gallo et al. 2007) raises concerns about the validity of that identification, particularly as it was not supported by a more elaborate description. The presence of $F$. heimi in the Indian Ocean should therefore be treated with caution. A lack of taxonomic knowledge relating to the delineation of morphologically similar species similarly contributed to misleadingly wide geographic ranges in some marine animals (e.g. Cerca et al. 2020). Conversely, evidence from other meiofaunal groups supports a cosmopolitan distribution in many cases (e.g. Meyer-Wachsmuth et al. 2014).

Supplementary Information Live male of Florarctus heimi collected in Shark Bay, Heron Island; Australia. The male just after mating with a female. One of the primary clavae is broken after the copulation. The online version contains supplementary material available at https://doi. org/10.1007/s12526-021-01183-y.

Acknowledgements The Associate Editor, Dr. Alejandro Martínez García, and two anonymous reviewers greatly improved this manuscript and are thanked for their help. Brian Blagden kindly reviewed the language. We are very grateful for the loan of the type materials of Florarctus heimi and the former F. cervinus from the National Museum of Natural History (Paris, France). The Australian Biological Resources Study, Carlsberg Foundation and Danish Research Agency financed this contribution. Jesper G. Hansen kindly agreed to us using a fragment of his $\mathrm{PhD}$ thesis in this contribution. Niels Svennevig and Stine Elle are gratefully acknowledged for the material collection and preparation of the drawings, respectively. Laura Pavesi (NHMD) is acknowledged for the registration and labelling of the slides. PG is a recipient of the 'Etiuda' (2020/36/T/NZ8/00360, funded by the National Science Centre) and 'Start' stipends (START 28.2020, funded by the Foundation for Polish Science).

Funding This study was funded by the Carlsberg Foundation (970345/ 30-488). 


\section{Declarations}

Conflict of interest The authors declare that they have no conflict of interest.

Ethical approval All applicable international, national and/or institutional guidelines for animal testing, animal care and use of animals were followed by the authors.

Sampling and field studies All necessary permits for sampling and observational field studies were obtained by the authors from the competent authorities and are mentioned in the Acknowledgements. The study is compliant with CBD and Nagoya protocols.

Data availability All data generated or analysed during this study are included in this published article and its supplementary information files.

Author contribution RMK conceived and designed the research. DMK and RMK conducted the sampling and field observations. PG and RMK analysed the data. All authors wrote, read and approved the manuscript.

Open Access This article is licensed under a Creative Commons Attribution 4.0 International License, which permits use, sharing, adaptation, distribution and reproduction in any medium or format, as long as you give appropriate credit to the original author(s) and the source, provide a link to the Creative Commons licence, and indicate if changes were made. The images or other third party material in this article are included in the article's Creative Commons licence, unless indicated otherwise in a credit line to the material. If material is not included in the article's Creative Commons licence and your intended use is not permitted by statutory regulation or exceeds the permitted use, you will need to obtain permission directly from the copyright holder. To view a copy of this licence, visit http://creativecommons.org/licenses/by/4.0/.

\section{References}

Altiero T, Suzuki AC, Rebecchi L (2018) Reproduction, development and life cycles. In: Schill RO (ed) Water bears: the biology of tardigrades. Zoological Monographs, vol 2, Chapter 8, pp 211-247. https://doi.org/10.1007/978-3-319-95702-9_8

Anguas-Escalante A, de Jesús-Navarrete A, DeMilio E, Pérez-Pech WA, Hansen JG (2020) A new species of Tardigrada from a Caribbean reef lagoon, Florarctus yucatanensis sp. nov. (Halechiniscidae: Florarctinae). Cah Biol Mar 61:377-385. https://doi.org/10.21411/ CBM.A.CD1B185A

Bartel S, Hohberg K (2020) Experimental investigations on the partnerfinding behaviour of Isohypsibius dastychi (Isohypsibiidae: Tardigrada). Zool J Linnean Soc 188:878-886. https://doi.org/10. 1093/zoolinnean/zlz076

Bartels PJ, Fontoura P, Nelson DR (2015) New records of marine tardigrades from Moorea, French Polynesia, with the description of Styraconyx turbinarium sp. nov. (Arthrotardigrada, Halechiniscidae). Zootaxa 3955:389-402. https://doi.org/10. 11646/zootaxa.3955.3.6

Bartels PJ, Apodaca JJ, Mora C, Nelson DR (2016) A global biodiversity estimate of a poorly known taxon: phylum Tardigrada. Zool J Linnean Soc 178:730-736. https://doi.org/10.1111/zoj.12441

Bartels PJ, Fontoura P, Nelson DR (2018) Marine tardigrades of the Bahamas with the description of two new species and updated keys to the species of Anisonyches and Archechiniscus. Zootaxa 4420: 43-70. https://doi.org/10.11646/zootaxa.4420.1.3
Bingemer J, Hohberg K, Schill RO (2016) First detailed observations on tardigrade mating behaviour and some aspects of the life history of Isohypsibius dastychi Pilato, Bertolani \& Binda 1982 (Tardigrada, Isohypsibiidae). Zool J Linnean Soc 178:856-862. https://doi.org/ 10.1111/zoj.12435

Blaxter M, Elsworth B, Daub J (2004) DNA taxonomy of a neglected animal phylum: an unexpected diversity of tardigrades. Proc Roy Soc London B (Suppl) 271:189-192. https://doi.org/10.1098/rsbl. 2003.0130

Briggs JC, Bowen BW (2012) A realignment of marine biogeographic provinces with particular reference to fish distributions. J Biogeogr 39:12-30. https://doi.org/10.1111/j.1365-2699.2011.02613.x

Briggs RT, Moss BL (1997) Ultrastructure of the coxal gland of the horseshoe crab Limulus polyphemus: evidence for ultrafiltration and osmoregulation. J Morphol 234:233-252. https://doi.org/10. 1002/(SICI)1097-4687(199712)234:3<233::AID-JMOR3>3.0.CO; 2-A

Buskey EJ (1998) Components of mating behavior in planktonic copepods. J Mar Syst 15:13-21. https://doi.org/10.1016/S0924-7963(97) 00045-6

Cerca J, Meyer C, Purschke G, Struck TH (2020) Delimitation of cryptic species drastically reduces the geographical ranges of marine interstitial ghost-worms (Stygocapitella; Annelida, Sedentaria). Mol Phylogenet Evol 143:106663. https://doi.org/10.1016/j.ympev. 2019.106663

Chang CY, Rho HS (1997) Two new marine tardigrades from Palawan Island, the Philippines. Korean J Biol Sci 1:323-331. https://doi.org/ 10.1080/12265071.1998.9647426

Curini-Galletti M, Artois T, Delogu V, De Smet WH, Fontaneto D, Jondelius U, Leasi F, Martínez A, Meyer-Wachsmuth I, Nilsson KS, Tongiorgi P, Worsaae K, Todaro MA (2012) Patterns of diversity in soft-bodied meiofauna: dispersal ability and body size matter. PLoS One 7:e33801. https://doi.org/10.1371/journal.pone.0033801

D’Addabbo Gallo M, Morone De Lucia MR, de Zio Grimaldi S (1989) Two new species of the genus Styraconyx (Tardigrada: Heterotardigrada). Cah Biol Mar 30:17-33. https://doi.org/10. 21411/CBM.A.7FABE03

de Zio Grimaldi S, Lamarca A, D’Addabbo Gallo M, Pietanza R (1999) Florarctinae of Asdhu Island, Maldives, Indian Ocean (Tardigrada, Heterotardigrada). Ital J Zool 66:383-391. https://doi.org/10.1080/ 11250009909356282

Degma P, Guidetti R (2018) Tardigrade taxa. In: Schill RO (ed) Water bears: the biology of tardigrades. Zoological Monographs 2 . Chapter 15:371-409. https://doi.org/10.1007/978-3-319-95702-9 15

Delamare-Deboutteville C, Renaud-Mornant J (1965) Un remarquable genre de Tardigrades des sables coralliens de Nouvelle-Calédonie. C R Acad Sci Paris 266:2581-2583

Dewel RA, Nelson DR, Dewell WC (1993) Tardigrada. In: Harrison WE, Rice ME (eds) Microscopic anatomy of invertebrates. Volume 12: Onychophora, Chilopoda and Lesser Protostomata. Chapter 5:143183

Doe DA, Smith JPS (2016) Structure of the male copulatory apparatus in Prognathorhynchus busheki (Platyhelminthes, Kalyptorhynchia). Invertebr Biol 135:150-162. https://doi.org/10.1111/ivb.12125

Doyère LM (1840) Mémoire sur les Tardigrades. Ann Sci Nat Paris, Sér 2 14:269-361

du Bois Reymond Marcus E (1952) On South American Malacopoda. Bol Fac Fil Ciên Letr Univ S Paulo, Zool 17:189-209

Fontoura P, Bartels PJ, Jørgensen A, Kristensen RM, Hansen JG (2017) An illustrated dichotomous key to the genera of marine heterotardigrades (Tardigrada). Zootaxa 4294:1-45. https://doi.org/ 10.11646/zootaxa.4294.1.1

Fujimoto S (2015) Halechiniscidae (Heterotardigrada, Arthrotardigrada) of Oura Bay, Okinawajima, Ryuku Islands, with descriptions of 
three new species. ZooKeys 483:149-166. https://doi.org/10.3897/ zookeys.483.8936

Fujimoto S, Jørgensen A, Hansen JG (2017) A molecular approach to arthrotardigrade phylogeny (Heterotardigrada, Tardigrada). Zool Scr 46:496-505. https://doi.org/10.1111/zsc.12221

Gallo M, D'Addabbo R, De Leonardis C, Sandulli R, de Zio GS (2007) The diversity of Indian Ocean Heterotardigrada. J Limnol 66(S1): 60-64. https://doi.org/10.4081/jlimnol.2007.s1.60

Gassiorek P, Stec D, Morek W, Michalczyk Ł (2019) Deceptive conservatism of claws: distinct phyletic lineages concealed within Isohypsibioidea (Eutardigrada) revealed by molecular and morphological evidence. Contrib Zool 88:78-132. https://doi.org/10.1163/ 18759866-20191350

Gilbert JJ (1963) Contact chemoreception, mating behavior, and sexual isolation in the rotifer genus Brachionus. J Exp Biol 40:625-641

Gomes-Júnior E, Santos É, da Rocha CMC, Santos PJP, Fontoura P (2018) A new species of Ligiarctus (Tardigrada, Arthrotardigrada) from the Brazilian continental shelf, Southwestern Atlantic Ocean. Mar Biodivers 48:5-12. https://doi.org/10.1007/s12526-017-0709-0

Grimaldi de Zio S, D'Addabbo Gallo M (1975) Reproductive cycle of Batillipes pennaki Marcus (Heterotardigrada) and observations on the morphology of the female genital apparatus. Pubbl Staz Zool Napoli 39(Suppl):212-225

Hansen JG (2011) The phylogeny of Arthrotardigrada. PhD thesis. Natural History Museum of Denmark, University of Copenhagen

Hansen JG, Kristensen RM (2020) Tardigrada. In: Schmidt-Rhaesa A (ed) Guide to the identification of marine meiofauna, Pfeil-Verlag, Munich, Germany, Chapter, vol 23, pp 428-444

Hansen JG, Jørgensen A, Kristensen RM (2001) Preliminary studies of the tardigrade fauna of the Faroe Bank. Zool Anz 240:385-393. https://doi.org/10.1078/0044-5231-00046

Hansen JG, Kristensen RM, Jørgensen A, Accogli G, D’Addabbo R, Gallo M (2016) Postembryonic development, paedomorphosis, secondary sexual dimorphism and population structure of a new Florarctus species (Tardigrada, Heterotardigrada). Zool J Linnean Soc 178:871-877. https://doi.org/10.1111/zoj.12436

Jensen P (1982) Reproductive behaviour of the free-living marine nematode Chromadorita tenuis. Mar Ecol Prog Ser 10:89-95

Jeon D, Lim D, Lee W, Soh HY (2018) First use of molecular evidence to match sexes in the Monstrilloida (Crustacea: Copepoda), and taxonomic implications of the newly recognized and described, partly Maemonstrilla-like females of Monstrillopsis longilobata Lee, Kim \& Chang, 2016. PeerJ 6:e4938. https://doi.org/10.7717/peerj.4938

Jørgensen A, Møbjerg N, Kristensen RM (1999) Ultrastructural studies on spermiogenesis and postcopulatory modifications of spermatozoa of Actinarctus doryphorus Schulz, 1935 (Arthrotardigrada: Halechiniscidae). Zool Anz 238:235-257

Jørgensen A, Boesgaard TM, Møbjerg N, Kristensen RM (2014) The tardigrade fauna of Australian marine caves: with descriptions of nine new species of Arthrotardigrada. Zootaxa 3802:401-443. https://doi.org/10.11646/zootaxa.3802.4.1

Jörger KM, Heß M, Neusser TP, Schrödl M (2009) Sex in the beach: spermatophores, dermal insemination and 3D sperm ultrastructure of the aphallic mesopsammic Pontohedyle milaschewitchii (Acochlidia, Opisthobranchia, Gastropoda). Mar Biol 156:11591170. https://doi.org/10.1007/s00227-009-1158-5

Jouin C (1968) Sexualité et biologie de la reproduction chez Mesonerilla Remane et Meganerilla Boaden (Archiannélides Nérillidae). Cah Biol Mar 9:31-52. https://doi.org/10.21411/CBM.A.7F6AD3AE

Kaczmarek Ł, Bartels PJ, Roszkowska M, Nelson DR (2015) The zoogeography of marine Tardigrada. Zootaxa 4037:1-189. https://doi. org/10.11646/zootaxa.4037.1.1

Karanovic T (2008) Marine interstitial Poecilostomatoida and Cyclopoida (Copepoda) of Australia. Crustac Monogr 9:1-331. https://doi.org/10.1163/ej.9789004164598.i-332
Kershaw DR (1983) The minor coelomate phyla. In: Kershaw DR (ed) Animal diversity. Springer, Dordrecht, pp 195-208. https://doi.org/ 10.1007/978-94-011-6035-3 12

Kristensen RM (1978) Notes on marine heterotardigrades. 1. Description of two new Batillipes species, using the electron microscope. Zool Anz 200:1-17

Kristensen RM (1979) On the fine structure of Batillipes noerrevangi Kristensen, 1978 (Heterotardigrada). 3. Spermiogenesis. Zesz Nauk Uniw Jagiell 529:97-105

Kristensen RM (1980) Zur Biologie des marinen Heterotardigraden Tetrakentron synaptae. Helgoländer Meeresun 34:165-177. https://doi.org/10.1007/BF01984038

Kristensen RM (1982) The first record of cyclomorphosis in Tardigrada based on a new genus and species from Arctic meiobenthos. J Zool Syst Evol Res 20:249-270. https://doi.org/10.1111/j.14390469. 1983.tb00552.x

Kristensen RM (1983) Loricifera, a new phylum with Aschelminthes characters from the meiobenthos. J Zool Syst Evol Res 21:163180. https://doi.org/10.1111/j.1439-0469.1983.tb00285.x

Kristensen RM (1984) On the biology of Wingstrandarctus corallinus nov. gen. et spec., with notes on the symbiotic bacteria in the subfamily Florarctinae (Arthrotardigrada). Vidensk Meddel Naturhist Foren 145:201-218

Kristensen RM (2003) Extreme secondary sexual dimorphism in the genus Florarctus (Arthrotardigrada: Halechiniscidae). Book of abstracts of $9^{\text {th }}$ International Symposium on Tardigrada. St. Pete Beach, Florida, USA, p 34

Kristensen RM, Hallas TE (1980) The tidal genus Echiniscoides and its variability, with erection of Echiniscoididae fam. n. (Tardigrada). Zool Scr 9:113-127. https://doi.org/10.1111/j.1463-6409.1980. tb00657.x

Kristensen RM, Higgins RP (1989) Marine Tardigrada from the Southeastern United States coastal waters. I. Paradoxipus orzeliscoides $\mathrm{n}$. gen., n. sp. (Arthrotardigrada: Halechiniscidae). Trans Amer Micr Soc 108:262-282. https://doi.org/10.2307/ 3226344

Marcus E (1927) Zur Anatomie und Ökologie mariner Tardigraden. Zool Jahrb Abt Syst Ökol Geog Tier 53:487-588

Martínez A, Eckert EM, Artois T, Careddu G, Casu M, Curini-Galletti M, Gazale V, Gobert S, Ivanenko VN, Jondelius U, Marzano M, Pesole G, Zanello A, Todaro MA, Fontaneto D (2020) Human access impacts biodiversity of microscopic animals in sandy beaches. Commun Biol 3:175. https://doi.org/10.1038/s42003-020-0912-6

Meyer-Wachsmuth I, Curini Galletti M, Jondelius U (2014) Hypercryptic marine meiofauna: species complexes in Nemertodermatida. PLoS One 9:e107688. https://doi.org/10.1371/ journal.pone. 0107688

Møbjerg N, Jørgensen A, Kristensen RM, Neves RC (2018) Morphology and functional anatomy. In: Schill RO (ed) Water bears: the biology of tardigrades, Zoological Monographs, vol 2, Chapter 2, pp 57-94. https://doi.org/10.1007/978-3-319-95702-9_2

Nagasawa S (1985) Copulation in the neritic chaetognath Sagitta crassa. J Plankton Res 7:927-935. https://doi.org/10.1093/plankt/7.6.927

Neuhaus B, Higgins RP (2002) Ultrastructure, biology, and phylogenetic relationships of Kinorhyncha. Integr Comp Biol 42:619-632. https://doi.org/10.1093/icb/42.3.619

Noda H (1987) A new species of marine Tardigrada of the genus Florarctus (Heterotardigrada, Halechiniscidae) from Japan. Publ Seto Mar Biol Lab 32:323-328

Pollock LW (1970) Batillipes dicrocercus n. sp., Stygarctus granulatus n. sp. and other Tardigrada from Woods Hole, Massachusetts, U.S.A. Trans Amer Micr Soc 89:38-52. https://doi.org/10.2307/3224613

Pollock LW (1995) New marine tardigrades from Hawaiian beach sand and phylogeny of the family Halechiniscidae. Invertebr Biol 114: 220-235. https://doi.org/10.2307/3226877 
Ramazzotti G (1972) Tardigradi delle Isole Kerguelen e descrizione della nuova specie Hypsibius (I.) renaudi. Mem Ist Ital Idrobiol 29:141144

Rawlinson KA, Bolaños DM, Liana MK, Litvaitis MK (2008) Reproduction, development and parental care in two directdeveloping flatworms (Platyhelminthes: Polycladida: Acotylea). J Nat Hist 42:2173-2192. https://doi.org/10.1080/ 00222930802262758

Rebecchi L, Nelson DR (1998) Evaluation of a secondary sex character in eutardigrades. Invertebr Biol 117:194-198. https://doi.org/10.2307/ 3226985

Renaud-Mornant J (1967) Tardigrades de la Baie Saint-Vincent, Nouvelle Calédonie. In: Expédition française sur les récifs coralliens de la Nouvelle-Calédonie. Fondation Singer-Polignac, Paris, vol 12, pp 103-118

Renaud-Mornant J (1970) Tardigrades marines des Bermudes. Bull Mus Natl d'Hist Nat, 2e sér 42:1268-1276

Renaud-Mornant J (1976) Le genere Florarctus Delamare-Deboutteville et Renaud-Mornant, 1965, en Méditerranée; description de deux espèces nouvelles (Arthrotardigrada). Bull Mus Natl d'Hist Nat, 3e sér 369:325-333

Renaud-Mornant J (1982) Sous-famille et genre nouveaux de tardigrades marins (Arthrotardigrada). Bull Mus Natl d'Hist Nat, 4e sér 4:89-94

Renaud-Mornant J (1987) Halechiniscidae nouveaux de sables coralliens tropicaux (Tardigrada, Artrotaradigrada). Bull Mus Natl d'Hist Nat, 4e sér 9:353-373

Renaud-Mornant J (1989) Espèces nouvelles de Florarctinae de l'Atlantique Nord-Est et du Pacifique Sud (Tardigrada, Arthrotardigrada). Bull Mus Natl d'Hist Nat A 11:571-592

Renaud-Mornant J, Gourbault N (1980) Survie de la méiofaune après l'échouement del'Amoco-Cadiz (chenal de Morlaix, grève de Roscoff). Bull Mus Natl d'Hist Nat, 4e sér 2:759-772

Rex MA (1973) Deep-sea species diversity: decreased gastropod diversity at abyssal depths. Science 181:1051-1053. https://doi.org/10. 1126/science. 181.4104 .1051

Rex MA (1981) Community structure in the deep-sea benthos. Annu Rev Ecol Syst 12:331-353. https://doi.org/10.1146/annurev.es.12. 110181.001555

Rico-Martínez R, Snell TW (1997) Mating behavior in eight rotifer species: using cross-mating tests to study species boundaries. Hydrobiologia 356:165-173. https://doi.org/10.1023/A: 1003194216467

Rico-Martínez R, Walsh EJ (2013) Sexual reproductive biology of a colonial rotifer Sinantherina socialis (Rotifera: Monogononta): do mating strategies vary between colonial and solitary rotifer species? Mar Freshw Behav Physiol 46:419-430. https://doi.org/10.1080/ 10236244.2013 .834110

Roberts CM, McClean CJ, Vernon JEN, Hawkins JP, Allen GR, McAllister DE, Mittermeier CG, Schueler FW, Spalding M, Wells F, Vynne C, Werner TB (2002) Marine biodiversity hotspots and conservation priorities for tropical reefs. Science 295:1280-1284. https://doi.org/10.1126/science.1067728

Ruppert EE (1978a) The reproductive system of gastrotrichs. II Insemination in Macrodasys: a unique mode of sperm transfer in Metazoa. Zoomorphology 89:207-228. https://doi.org/10.1007/ BF00993948

Ruppert EE (1978b) The reproductive system of gastrotrichs. III Genital organs of Thaumastodermatinae subfam. $n$. and Diplodasyinae subfam. n. with discussion of reproduction in Macrodasyida. Zool Scr 7:93-114. https://doi.org/10.1111/j.1463-6409.1978.tb00592.x

Santos E, Veiga P, Rubal M, Bartels PJ, da Rocha CMC, Fontoura P (2019) Batillipes pennaki Marcus, 1946 (Arthrotardigrada:
Batillipedidae): deciphering a species complex. Zootaxa 4648: 549-567. https://doi.org/10.11646/zootaxa.4648.3.9

Schmidt-Rhaesa A (2020) Guide to the identification of marine meiofauna. Pfeil-Verlag, Munich, Germany

Schratzberger M, Ingels J (2018) Meiofauna matters: the roles of meiofauna in benthic ecosystems. J Exp Mar Biol 502:12-25. https://doi.org/10.1016/j.jembe.2017.01.007

Sella G, Ramella L (1999) Sexual conflict and mating systems in the dorvilleid genus Ophryotrocha and the dinophilid genus Dinophilus. Hydrobiologia 402:203-213. https://doi.org/10.1023/ A: 1003748710921

Sterrer W (1972) Systematics and evolution within the Gnathostomulida. Syst Zool 21:151-173. https://doi.org/10.1093/sysbio/21.2.151

Sterrer W, Sørensen MV (2015) Phylum Gnathostomulida. In: SchmidtRhaesa A (ed) Handbook of zoology, Volume 3. Gastrotricha and Gnathifera 2:135-196. https://doi.org/10.1515/9783110274271.135

Sugiura K, Minato H, Suzuki AC, Arakawa K, Kunieda T, Matsumoto M (2019) Comparison of sexual reproductive behaviors in two species of Macrobiotidae (Tardigrada: Eutardigrada). Zool Sci 36:120-127. https://doi.org/10.2108/zs180103

Suzuki AC (2008) Appearance of males in a thelytokous strain of Milnesium cf. tardigradum (Tardigrada). Zool Sci 25:849-853. https://doi.org/10.2108/zsj.25.849

Suzuki AC, Kristensen RM (2014) Spermatozoa in the reproductive system of a hermaphroditic marine tardigrade, Orzeliscus belopus (Tardigrada: Arthrotardigrada). Zool Anz 253:497-511. https://doi. org/10.1016/j.jcz.2014.07.003

Thiel M (1999) Duration of extended parental care in marine amphipods. J Crustac Biol 19:60-71. https://doi.org/10.1163/ 193724099X00259

Thiel M, Duffy JE (2007) The behavioral ecology of crustaceans. A primer in taxonomy and functional biology. In: Duffy JE, Thiel M (eds) Evolutionary ecology of social and sexual systems: crustaceans as model organisms. Oxford University Press, New York, USA, pp 3-28. https://doi.org/10.1093/acprof:oso/ 9780195179927.003.0001

Thulin G (1928) Über die Phylogenie und das System der Tardigraden. Hereditas 11:207-266. https://doi.org/10.1111/j.1601-5223.1928. tb02488.x

Tsurusaki N (1980) A new species of marine interstitial Tardigrada of genus Hypsibius from Hokkaido, Northern Japan. Annot Zool Jpn 53:280-284

Uchima M, Murano M (1988) Mating behavior of the marine copepod Oithona davisae. Mar Biol 99:39-45. https://doi.org/10.1007/ BF00644975

van der Land J (1968) Florarctus antillensis, a new tardigrade from the coral sands of Cura ao. Stud Faun Curaçao Carib Isl 25:140-146

Velázquez-Rojas CA, Santos-Medrano GE, Rico-Martínez R (2002) Sexual reproductive biology of Platyias quadricornis (Rotifera: Monogononta). Int Rev Hydrobiol 87:97-105. https://doi.org/10. 1002/1522-2632(200201)87:1<97::AID-IROH97>3.0.CO;2-\%23

von Erlanger R (1895) Beiträge zur Morphologie der Tardigraden. I. Zur Embryologie eines Tardigrade Macrobiotus macronyx Dujardin. Morphol Jahrb 22:491-513

Westheide W (1978) Ultrastructure of the genital organs in interstitial polychaetes. I. Structure, development, and function of the copulatory stylets in Microphthalmus cf. listensis. Zoomorphologie 91: 101-118. https://doi.org/10.1007/BF00993855

Publisher's note Springer Nature remains neutral with regard to jurisdictional claims in published maps and institutional affiliations. 